\title{
GAMBARAN PERAN KADER KESEHATAN DALAM MENYUKSESKAN PROGRAM KB PADA MASA PANDEMI COVID-19 DI WILAYAH KERJA PUSKESMAS MARGA I
}

\author{
Kadek Sri Ariyanti ${ }^{1}$, Ni Made Indra Peratiwi ${ }^{2}$, Ni Luh Kristin Permata Sari ${ }^{3}$ \\ 1,2,3Program Studi Diploma III Kebidanan STIKES Advaita Medika Tabanan \\ Korespondensi penulis: ariyanthi.midwife@gmail.com
}

\begin{abstract}
Abstrak
Latar belakang: Kondisi pandemi menimbulkan kekhawatiran adanya lonjakan kelahiran bayi atau baby boom pasca pandemi Covid-19. Peran kader kesehatan dalam menyukseskan program $\mathrm{KB}$ dalam situasi ini sangat diperlukan, mengingat kecemasan masyarakat untuk datang ke tempat layanan kesehatan cukup tinggi.

Tujuan: Penelitian ini bertujuan untuk mengetahui gambaran peran kader kesehatan dalam menyukseskan program KB pada masa Pandemi Covid-19 di Wilayah Kerja Puskesmas Marga I.

Metode: Jenis penelitian ini adalah deskriptif dengan rancangan cross sectional. Populasi dalam penelitian ini adalah kader kesehatan di Wilayah Kerja Puskesmas Marga I dengan jumlah 125 orang. Sampel berjumlah 124 orang yang diambil dengan teknik total sampling. Instrumen dalam penelitian ini menggunakan kuesioner yang disebarkan secara online melalui google form. Analisa data dengan cara deskriptif untuk memperoleh distribusi frekwensi variabel.

Hasil: Dari hasil penelitian diperoleh bahwa kader kesehatan yang memberikan informasi tentang KB sebanyak $67 \%$. Informasi yang diberikan sebagian besar melalui whatsapp yaitu sebesar $63 \%$. Sebagian kecil kader memberikan informasi melalui leaflet/brosur (43\%) dan melakukan kunjungan rumah (40\%).

Simpulan: Kader lebih gencar memberikan informasi tentang KB pada masa pandemi Covid-19 sebagai upaya untuk menyukseskan program KB di Indonesia.
\end{abstract}

Kata kunci: Kader, Pandemi Covid-19, Peran, Program KB

\section{Pendahuluan}

Pelayanan KB mendapat dampak yang cukup besar selama Pandemi Covid-19. Pelayanan KB yang dilakukan dalam masa pandemi Covid-19 dapat melalui baksos dan penyuluhan-penyuluhan yang dilakukan oleh Penyuluh Keluarga Berencana (PLKB) atau kader-kader kesehatan. Sehingga ketika diterapkannya social distancing maka akan terjadi penurunan cakupan layanan KB mengingat kecemasan masyarakat untuk datang ke tempat layanan kesehatan cukup tinggi (Dwiana, 2020).

Kondisi pandemi ini menimbulkan kekhawatiran adanya lonjakan kelahiran bayi atau baby boom pasca pandemi Covid-19. Akibat dari pandemi Covid-19 berimbas pada penurunan peserta $\mathrm{KB}$, dimana terdapat penurunan peserta KB pada bulan Maret 2020 dibandingkan dengan bulan Februari 2020 di seluruh Indonesia (BKKBN, 2020).

Peran tenaga kesehatan maupun kader sangat penting untuk menunjang suksesnya program $\mathrm{KB}$, dimana peran kader tidak hanya memberikan edukasi tetapi juga memberikan dukungan kepada PUS dan WUS sehingga mereka memiliki kemauan untuk menggunakan KB. Dalam kondisi pandemi seperti ini membutuhkan perhatian yang lebih maksimal lagi karena kita harus memperhatikan protokol kesehatan dan masyarakat cenderung takut untuk keluar rumah dikarenakan takut tertular virus Covid-19. Kader maupun tenaga kesehatan harus mengambil tindakan dan membuat program untuk menyukseskan program $\mathrm{KB}$ 
baik melalui kunjungan rumah maupun melalui daring (Cristy, 2021).

Dari hasil studi pendahuluan yang dilakukan di wilayah kerja Puskesmas Marga I diketahui bahwa sebanyak $70 \%$ kader memberikan informasi melalui daring untuk menyukseskan program KB di masa Pandemi Covid-19. Oleh karena itu penulis tertarik untuk melakukan penelitian ini dengan tujuan untuk mengetahui gambaran peran kader kesehatan dalam menyukseskan Program KB di Masa Pandemi Covid-19 di Wilayah Kerja Puskesmas Marga I Tabanan. Adapun peran yang ingin penulis ketahui adalah melalui daring maupun luring.

\section{Metode Penelitian}

Jenis penelitian ini adalah deskriptif dengan rancangan cross sectional. Penelitian dilakukan di wilayah kerja Puskesmas Marga I pada tanggal 27 juni 2021 sampai 6 juli 2021. Populasi dalam penelitian ini adalah kader kesehatan di Wilayah Kerja Puskesmas Marga I dengan jumlah 140 orang. Sampel berjumlah 124 orang yang diambil dengan teknik random sampling dengan cara undian. Instrumen dalam penelitian ini menggunakan kuesioner yang disebarkan secara online melalui google form. Analisa data dengan cara deskriptif untuk memperoleh distribusi frekwensi variabel.

\section{Hasil dan Pembahasan}

Tabel 1. Karakteristik Responden

\begin{tabular}{ccc}
\hline Karakteristik & Frekuensi (f) & Persentase (\%) \\
\hline Umur & 50 & 40 \\
$20-30$ tahun & 71 & 57 \\
$31-40$ tahun & 3 & 3 \\
$41-50$ tahun & & \\
Pendidikan & 0 & 0 \\
SD & 0 & 0 \\
SMP & 114 & 92 \\
SMA/SMK & 10 & 9 \\
PT & $\mathbf{1 2 4}$ & $\mathbf{1 0 0}$ \\
\hline Total & &
\end{tabular}

Tabel 2. Gambaran Peran Kader dalam Menyukseskan Program KB pada Masa Pandemi Covid-19 di Wilayah Kerja Puskesmas Marga I

\begin{tabular}{|c|c|c|c|}
\hline No. & Pengetahuan & Frekuensi (f) & Persentase (\%) \\
\hline \multirow[t]{3}{*}{1} & $\begin{array}{l}\text { Memberikan informasi tentang KB pada masa pandemi } \\
\text { Covid-19 }\end{array}$ & & \\
\hline & $\mathrm{Ya}$ & 83 & 67 \\
\hline & Tidak & 41 & 33 \\
\hline \multirow[t]{5}{*}{2} & Memberikan informasi melalui media sosial & & \\
\hline & Whatsapp & 79 & 63 \\
\hline & Facebook & 4 & 4 \\
\hline & Instagram & 0 & 0 \\
\hline & Lainnya & 0 & 0 \\
\hline \multirow[t]{3}{*}{3} & Memberikan leaflet/brosus & & \\
\hline & $\mathrm{Ya}$ & 53 & 43 \\
\hline & Tidak & 71 & 67 \\
\hline \multirow[t]{3}{*}{4} & Melakukan kunjungan rumah & & \\
\hline & $\mathrm{Ya}$ & 49 & 40 \\
\hline & Tidak & 75 & 60 \\
\hline \multirow[t]{3}{*}{5} & Mengalami Kendala & & \\
\hline & $\mathrm{Ya}$ & 110 & 89 \\
\hline & Tidak & 14 & 11 \\
\hline
\end{tabular}


$6 \quad$ Kendala yang dialami:

$\begin{array}{lll}\text { Akses informasi } & 37 & 30\end{array}$

$\begin{array}{lll}\text { Akses pelayanan } & 18 & 15\end{array}$

Pandemi yang menghalangi program yang dijalankan $\quad 60 \quad 48$

Waktu dan jarak tempuh

$9+7$

Dari tabel 1 di atas dapat dilihat bahwa sebagian besar responden berusia $31-40$ tahun, yaitu sebesar 57\%. Dilihat dari segi pendidikan, sebagian besar responden berpendidikan SMA, yaitu sebesar 92\%.

Berdasarkan Tabel 2 di atas dapat diketahui bahwa sebanyak $67 \%$ kader memberikan informasi tentang $\mathrm{KB}$ di masa Pandemi Covid-19. Sebagian besar kader memberikan informasi tentang $\mathrm{KB}$ melalui media social whatsapp, yaitu sebesar $63 \%$. Kader yang memberikan informasi melalui leaflet/ brosur sebanyak $43 \%$ dan melakukan kunjungan rumah yaitu sebanyak $40 \%$. Responden kader yang mengalami kendala sebanyak. Sebagian besar kader mengalami kendala dalam memberikan informasi selama pandemic Covid-19, yaitu sebesar 89\%. Kendala yang dialami antara lain: kurangnya akses informasi sebanyak $30 \%$, akses ke layanan kesehatan sebanyak 15\%, pandemi menghalangi program yang dijalankan sebanyak $48 \%$ serta waktu dan jarak tempuh sebanyak $7 \%$.

Pemberian Informasi KB di Masa Pandemi Covid-19

Hasil penelitian menunjukkan bahwa sebagian besar kader memberikan informasi tentang KB di masa pandemi Covid-19, yaitu sebesar $67 \%$. Kader memberikan informasi melalui media social whatsapp sebanyak $63 \%$ dan facebook sebanyak $4 \%$.

Menurut Mubarak 2012 Pemberian informasi sangat diperlukan karena komunikasi bermanfaat untuk memperbaiki kurangnya pengetahuan dan sikap masyarakat yang salah terhadap kesehatan. Komunikasi dikatakan efektif jika mampu memberikan informasi secara jelas kepada pasien, sehingga dalam penanganan diharapkan tenaga kesehatan bersikap ramah dan sopan pada setiap kunjungan pasiennya. Peran tenaga kesehatan maupun kader sangat penting untuk menunjang suksesnya program $\mathrm{KB}$, dimana peran kader dan tenaga kesehatan tidak hanya memberikan edukasi tetapi juga memberikan dukungan kepada PUS dan WUS sehingga mereka memiliki kemauan untuk menggunakan $\mathrm{KB}$ dan mengetahui tentang KB. Dengan meningkatnya pengetahuan ibu tentang alat dan metode KB, diharapkan dapat mempengaruhi sikap ibu dalam memilih dan menggunakan alat kontrasepsi yang tepat sehingga diharapkan dapat membatasi jumlah kelahiran anak dan menurunkan dampak baby booms (Purwanti, 2021)

Media aplikasi memberikan kemudahan akses bagi publik dalam menerima informasi. Hal ini mengurangi interaksi langsung dengan PUS sehingga diharapkan dapat mengurangi terjadinya kerumunan. Secara tidak langsung ini merupakan antisipasi agar tidak terpapar virus Covid-19 dimana masyarakat bisa mengakses informasi terkait metode kontrasepsi melalui aplikasi tanpa harus datang ke fasilitas kesehatan bila tidak bersifat urgent (Arsyad, 2017).

\section{Memberikan Informasi Melalui Leaflet}

Dari hasil penelitian dapat diketahui bahwa sebagian kecil kader yang memberikan informasi melalui leaflet sebanyak 43\%. Kader dapat memfasilitasi akseptor KB dengan leaflet/brosur atau poster tentang KB selama pandemic Covid19, sehingga informasi dapat tersampaikan meskipun melalui online maupun secara langsung dengan tetap mengikuti protokol kesehatan. Pengetahuan ibu tentang alat kontrasepsi sangat dibutuhkan dalam memilih alat kontrasepsi yang akan digunakan agar dapat memilih dengan tepat. Leaflet/brosur dan poster dapat memberikan informasi yang cukup kepada akseptor, sehingga bisa mempelajarinya dan dapat 
disimpan untuk dipelajari lebih lanjut oleh PUS (Sumarroh, 2015).

Pemberian Informasi KB Melalui Kunjungan Rumah

Hasil penelitian menunjukkan bahwa hanya sebagian kecil kader yang melakukan kunjungan rumah untuk memberikan informasi tentang KB selama Pandemi Covid-19. Hal ini disebabkan karena pada masa pandemi covid-19 kunjungan dibatasi untuk pencegahan penularan covid-19.

Pendampingan dan pemberian informasi secara langsung dengan cara melakukan kunjungan rumah dapat memberikan informasi yang lebih jelas dan dapat diterima baik oleh akseptor KB. Semakin banyak pemberian informasi tentang $\mathrm{KB}$ yang diberikan oleh kader, maka semakin banyak pula pengetahuan PUS tentang KB (Herawati, et al, 2020).

Kendala dalam Pemberian Informasi tentang KB di Masa Pandemi Covid-19

Hasil penelitian menunjukkan bahwa sebagian besar kader mengalami kendala dalam pemberian informasi tentang $\mathrm{KB}$ selama amsa Pandemi Covid-19, yaitu sebesar $89 \%$. Adapun kendala yang dialami antara lain: kurangnya akses informasi sebanyak 30\%, akses ke layanan kesehatan sebanyak $15 \%$, pandemi menghalangi program yang dijalankan sebanyak $48 \%$ serta waktu dan jarak tempuh sebanyak $7 \%$.

Kendala yang dialami oleh pemberian informasi atau komunikator merupakan adanya masalah yang dihadapi oleh komunikator yang biasa dicari pemecahan masalahnya melalui cara lain yang bisa dianggap hal yang paling mudah yang bisa dijadikan alternatif dari pemberian informasi. Pengetahuan terhadap alat kontrasepsi merupakan pertimbangan dalam menentukan metode kontrasepsi yang digunakan. Sedangkan salah satu faktor penghambat dalam kepesertaan KB yaitu adanya pandemi Covid-19, dimana masyarakat takut terpapar virus sehingga membatasi kegiatan keluar rumah. Jika semua perempuan mempunyai akses terhadap kontrasepsi yang aman dan efektif selama pandemi Covid-19, maka diperkirakan kematian ibu akan menurun termasuk menurunnya risiko kesehatan reproduksi yang terkait dengan kehamilan, persalinan, nifas dan aborsi yang tidak aman (Nainggolan, 2020).

\section{Simpulan}

Sebagian besar kader memberikan informasi tentang KB selama Pandemi Covid-19. Kader memberikan informasi paling banyak melalui media sosial whatsaap. Hanya sebagian kecil kader yang memberikan informasi melalui leaflet/brosur dan poster serta melakukan kunjungan rumah. Sebagian besar kader mengalami kendala dalam memberikan informasi tentang KB selama pandemi Covid-19. Kendala yang dialami sebagian besar adalah akibat adanya pandemi Covid-19 yang mengganggu kelancaran pelaksanaan program-program yang terkait dengan KB.

\section{Referensi}

BKKBN. 2015. Kebijakan Program Kependudukan, Keluarga Berencana, dan Pembangunan Keluarga. Jakarta: BKKBN

BKKBN. 2020. Peserta KB Aktif Menurut Metode Kontrasepsi Indonesia. Jakarta: BKKBN.

Cristy, 2020. Peran Tenaga Kesehatan Dan Kader dalam Menyukseskan program KB. Bali

Cristy, 2021. Peran Tenaga Kesehatan Dan Kader dalam Menyukseskan program KB. Bali

Effendi Nur Hasan, Mulyoto, Nunuk Suryani, 2013, Jurnal Teknologi Pendidikan, Volume 1, No 2, Halaman 214-225

Handayani, S. 2010. Buku Ajar Pelayanan Keluarga Berencana. Yogyakarta: Pustaka Rihama.

Mubarak, WI. (2007). Promosi Kesehatan Sebuah Pengantar Belajar Mengajar dalam Pendidikan. Yogyakarta : Graha Ilmu Pembangunan Keluarga. Jakarta: BKKBN.

Rismawati, S. 2012. UNMET NEED: Tantangan Program Keluarga 
Berencana dalam menghadapi

Ledakan Penduduk Tahun 2030.

Publikasi Penelitian. Bandung : Fakultas Kedokteran UNPAD.

Saryono, Setiawan Ari, 2011. Metode Penelitian Kebidanan DIII, DV,S1, dan S2. Yogyakarta: Nuha Medika

Sugiyono. 2011. Metode Penelitian Kuantitatif Kualitatif dan $R \& D$. Bandung: CV Alfabeta

Sulistyaningsih. 2011. Metodologi Penelitian Kebidanan, Kuantitatif \& Kualitatif. Edisi Pertama, Yogyakarta : Graha Ilmu 